Law, Culture and the Humanities

\section{Recovering the Human in Human Rights}

(C) The Author(s) 2014

Reprints and permissions: sagepub.co.uk/journalsPermissions.nav DOI: 10.1 I77/I743872II 4528440 Ich.sagepub.com

(SAGE

\author{
Diana Tietjens Meyers \\ University of Connecticut, Storrs, USA
}

\begin{abstract}
It is often said that human rights are the rights that people possess simply in virtue of being human - that is, in virtue of their intrinsic, dignity-defining common humanity. Yet, on closer inspection the human rights landscape doesn't look so even. Once we bring perpetrators of human rights abuse and their victims into the picture, attributions of humanity to persons become unstable. In this article, I trace the ways in which rights discourse ascribes variable humanity to certain categories of people. I set the stage for my discussion of the human in relation to human rights by examining John Locke's account of the justification for punishment. For Locke, in committing a crime one abrogates one's humanity and forfeits one's rights. Likewise, I argue, human rights discourse takes a scalar view of humanity. I consider victims of genocide who are dehumanized as helpless and passive, victims of state persecution who are super-humanized as righteously agentic, and perpetrators of genocide who are dehumanized as out-of-control beasts. In each case I use relevant testimony to argue that the scalar view of humanity is factually incorrect and morally deplorable. For genocide victims, I discuss testimony that Selma Leydesdorff gathered from women who survived the Srebrenica massacre. For a victim of persecution, I discuss Liao Yiwu's memoire of his detention and imprisonment in China because of his artwork protesting the Tiananmen Square massacre. For perpetrators of genocide, I discuss testimony Jean Hatzfeld gathered from Hutu men who systematically murdered Tutsis in the Rwandan genocide. Finally, I apply my critique of dehumanized and super-humanized victims and dehumanized perpetrators to the problem of transnational trafficking in persons and argue that the view I advocate necessitates reforming immigration policy with respect to persons trafficked into forced labor.
\end{abstract}

\title{
Keywords
}

John Locke, human rights, victims, perpetrators, agency, vulnerability

\author{
Corresponding author: \\ Diana Tietjens Meyers, University of Connecticut, Philosophy, Storrs, CT 06269, USA. \\ Email: diana.meyers@uconn.edu
}


It is often said that human rights are the rights that people possess simply in virtue of being human - that is, in virtue of their intrinsic, dignity-defining common humanity. Yet, on closer inspection the human rights landscape doesn't look so even. Once we bring perpetrators of human rights abuse and their victims into the picture, attributions of humanity to persons become unstable. This article traces the ways in which rights discourse ascribes variable humanity to certain categories of people divesting some of them of their rights and conferring extra rights on others. To remedy this departure from the conception of humanity at the core of human rights culture, we need to conceptualize right-holders, including perpetrators and victims, as agentic and vulnerable subjects.

The confusion about the human in relation to human rights might have started with John Locke. Of course, Locke's theory of natural rights long predates and differs greatly from the corpus of declarations and treaties that we call human rights today. But his views are widely thought to be precursors, if not sources, of human rights doctrine. So it is noteworthy that Locke's theory of punishment introduces a scalar view of humanity that seems out of keeping with his theory of human equality but that human rights discourse preserves and magnifies.

Locke's justification for punishing persons whose birthright, after all, includes the rights to life, liberty, and property is strangely convoluted. These natural rights would seem to preclude punishing anyone, even for the most heinous crimes, for levying any type of punishment - the death penalty or other corporal punishment, imprisonment or forced labor, fines or confiscating other property - involves abridging one or more of these rights. Locke gets around this obstacle by declaring that committing a crime implies forfeiting your rights. ${ }^{1}$ Having abandoned reason and the moral law it prescribes, a murderer or a thief becomes a "noxious creature," no different from "a lion or a tiger, one of those savage beasts with which men can have no society or security." 2 You've disowned your humanity and with it your rights, and others may justly punish you, including by execution. Yet, there are lesser crimes, and Locke stresses that they must be punished proportionately. Punishments must be no more severe than is sufficient to deter others and induce the malefactor to repent. ${ }^{3}$ Reasonable as this proportionality claim is, it is far from clear how to fit it into the template for justifying punishment that Locke provides. Perhaps wrongdoers who commit minor crimes do not altogether abnegate reason and therefore do not forfeit their rights completely. Retaining some measure of their humanity, do they, then, forfeit just those entitlements that may be justifiably abridged in punishing the particular offense they've committed? Do the very penalties that suffice for purposes of deterrence and repentance invariably match up with the degree of humanity renounced and the precise configuration of rights forfeited? It's far from evident why this congruence would hold up.

1. As A. John Simmons puts it, "This forfeiture [of certain (or all) of their rights] accomplishes a 'lowering' of moral barriers to punishment." ("Locke on the Death Penalty," Philosophy 69(270) (1994), 471-7, 473).

2. John Locke, The Second Treatise of Government (Indianapolis, IN: Bobbs-Merrill, 1690/1952), chap. 2, sec. 10-11; chap. 3, sec 17-18.

3. Locke, chap. 2, sec. 12. 
Locke's account of punishment is metaphysically and meta-ethically strange, for it establishes a sliding scale of humanity and with it a sliding scale of rights forfeiture. To make sense of these scales, rights and humanity must be implausibly represented as quanta that co-vary and that may diminish or increase depending on moral merit. Those fully governed by reason are fully human; those who abrogate reason in relatively inconsequential ways are diminished in their humanity; those who defy the most serious dictates of reason are bestialized and dehumanized. Some of our vernacular expressions align with this way of thinking. For example, it's not uncommon to hear a person who has committed a particularly heinous crime called a monster, and many people who talk this way seem to regard such persons as deserving no moral consideration whatsoever. Along similar lines, Kay Schaffer and Sidonie Smith observe that prisoners on death row in the US today occupy a "degrading and dehumanizing zone of no-rights." 4 But unlike Locke, who would seem to have no principled objection to this state of affairs, ${ }^{5}$ Schaffer and Smith endorse initiatives that aim to recognize the humanity of these individuals and their status as bearers of human rights. I agree with Schaffer and Smith that the Lockean moral ontology is indefensible, and I'll defend my view by showing that commonplace understandings of what it is to be a victimizer or a victim, grounded as they are in Locke's scalar moral ontology, are distorted.

Insofar as prevalent conceptions of perpetrators and victims echo Locke's views about humanity and rights, we fail to realize human rights. Richard Rorty captures the view I propose to critique in affective terms:

The contempt we always feel for losers - Jews in the thirties, Muslims now - combines with our disgust at the winners' behavior to produce the semi-conscious attitude: "a plague on both your houses." 6

In this passage, the winners are perpetrators of atrocities, the losers are their victims, and we are the bystanders who are rationalizing our indifference and inaction. Schaffer and Smith reinforce Rorty's point in theoretical terms:

The human rights regime can only offer an imperfect response to the problem of human suffering in the world. It reifies the identities of "victim" and "perpetrator." ... It reproduces a circuit of demand in which the powerful and relatively privileged retain the right to confer or refuse recognition. ${ }^{?}$

In the discussion that follows, I lay out the faulty, hyperbolic conceptions of victims and perpetrators that are now in currency and urge that we need more true-to-life, ethically

4. Kay Schaffer and Sidonie Smith, Human Rights and Narrated Lives (New York: Palgrave Macmillan, 2004), p. 179.

5. But see Simmons (p. 474, cited above) for a persuasive argument that Locke would have no objection to a state that abolished the death penalty.

6. Richard Rorty, "Human Rights, Rationality, and Sentimentality," in On Human Rights. Ed. Stephen Shute and Susan Hurley (New York: Basic Books, 1993), p. 113.

7. Schaffer and Smith, p. 232. 
cogent conceptions - conceptions that make it more difficult to rationalize apathy in the face of human rights abuse. ${ }^{8}$

Wendy Brown and Martha Minow underscore the downside of claiming victim status. For Brown, human rights violations "become sites of the production and regulation of identity as injury" - that is, permanent victim identities. ${ }^{9}$ As a victim, your wounded self supplants everything else that you have been and might become. Minow worries about the ulterior purposes and toxic dynamics of "victim talk" - evading responsibility by claiming to be a victim, prompting alleged perpetrators to insist that they're the real victims, using emotion rather than facts to play on others' sympathies, and blaming real victims. ${ }^{10}$ In different respects, Brown and Minow see demanding acknowledgment as a victim as an exercise in futility. Whereas Brown condemns victim identities because they harden and block emancipatory projects, Minow condemns victim talk because it stagnates in charges and counter-charges and thwarts social problem solving.

Brown and Minow latch onto real problems in today's human rights discourse. But simply jettisoning victim claims isn't the answer. Human rights specify ways in which people can be seriously wronged, and to be seriously wronged is to be a victim in that respect. Yet, Brown and Minow both diagnose a pathology that has taken root in the regnant conception of a victim - the association between being a victim, on the one hand, and passivity and helplessness, on the other. ${ }^{11}$ There are historical as well as pragmatic reasons for this association. Historically, the human rights regime got its start in response to the atrocities committed in the Nazi concentration camps during World War II. Correlatively, the conception of a victim of human rights abuse was derived from reports of the cruelty, deprivation, and violence inmates endured in the camps together with the circulation of unforgettable photographs of the starving, naked people Allied troops discovered when they reached the camps. The enormity of this brutality and the corpselike imagery seemed to validate regarding these victims as helpless and passive. ${ }^{12}$ Pragmatically, ascribing helplessness and passivity to victims renders them innocent - i.e., absolves them of any responsibility for or complicity in their own suffering. As innocent victims, they deserve our sympathy, and they are entitled to see justice done.

This mid-twentieth century conception of victims lives on in recent human rights discourse. Psychologist Teufica Ibrahimefendić served as an expert witness regarding the trauma incurred by the Bosnian women who were present at Potočari, the site of the genocidal massacre of boys and men orchestrated by Serb forces in the environs of Srebrenica in 1995. I excerpt her 2000 testimony at the Tribunal for the Former Yugoslavia here:

8. For related discussion, see my "Two Victim Paradigms and the Problem of 'Impure' Victims." In Victims' Stories and the Advancement of Human Rights. Under contract to Oxford University Press.

9. Wendy Brown, States of Injury (Princeton, NJ: Princeton University Press, 1995), p. 134.

10. Martha Minow, "Surviving Victim Talk," UCLA Law Review 40 (1993), 1411-45, 1417.

11. Brown, p. 94; Minow, p. 1427.

12. I note, though, that there is ample evidence of mutual aid and protection among the camp inmates, not to mention other expressions of agency. 
This all took place in an atmosphere which was beyond their control; there was nothing they could have done. They were completely helpless. ${ }^{13}$

While it is undeniable that the terrorized women at Potočari could not have prevented the mass murder of their menfolk, Selma Leydesdorff's interviews with these women demonstrate unequivocally that they were neither "completely helpless" nor were they passive despite the chaos into which the encampment had been thrown. On the advice of the UN peacekeeping force in Srebrenica, Bosnian Muslims of all ages thronged to Potočari in blistering July heat. Once there, they were crowded into a compound without sanitary facilities, and they were given no food or water. The drunken Serb soldiers strutting around brandishing (and using) their weapons provoked incessant, ear-splitting screaming. Yet, one woman after another recounts searching for and reuniting family members, fetching water for a child or an elderly relative, finding a hiding place for herself and her children, or pleading to save a son's life. ${ }^{14}$ To be sure, these women were victims - they were deprived of every necessity; they were forced to witness unspeakable killings and mutilations; many were raped and/or beaten - but they were agentic subjects as well. In the riveting words of one anonymous woman, "I tried not to forget who I was." 15 In the midst of abomination and bedlam, she clung to her moral identity and struggled to preserve her dignity.

Imputing passivity and helplessness to victims dehumanizes them by stripping them of their capacity for rational choice and action - the grounding of human dignity according to Locke as well as Article 1 of the Universal Declaration of Human Rights. Although I find nothing in Locke's work to suggest that he saw victims of rights violations as dehumanized in this way, there can be no doubt that human rights discourse encodes this factually erroneous and morally deplorable dehumanization of victims. This implicit dehumanization is a major reason why many people who have in fact been victimized prefer to call themselves survivors. This choice of labels affirms their active coping with the suffering inflicted upon them thereby repudiating the wrongdoer's attempt to objectify them. Although threats or force may compel strategic submission or loss of control for a time, it is a misleading stereotype that associates victims with de-agentification. Indeed, a familiar class of victims defies this stereotype - the victims of tyranny for whom Amnesty International coined the expression "prisoner of conscience."16

No one denies that prisoners of conscience - individuals who are incarcerated and sometimes tortured for their peaceful opposition to state policies - are victims. Yet, their

13. Quoted in Selma Leydesdorff, Surviving the Bosnian Genocide: The Women of Srebrenica Speak, trans. Kay Richardson (Bloomington, IN: Indiana University Press, 2011), p. 204.

14. Leydesdorff, pp. 146, 168-75.

15. Leydesdorff, p. 168.

16. There is no precise analogue in Locke for prisoners of conscience. The closest approximation is his treatment of rebels who having suffered violence and injury amounting to tyranny at the hands of the state and who have no alternative but to "appeal to heaven" - that is, to revolt against the established but illegitimate government (Ch. 3, Sec. 20; Ch. 18, Sec. 209; Ch. 19, Sec. 240-1). However, there's no hint in Locke's text of glorifying rebels, the righteousness of their cause notwithstanding. 
active resistance to policies they deem unjust spurs government officials to take measures to silence them, and their refusal to buckle under state repression is lionized. Conspicuously not passive and not helpless as they confront oppression and rally supporters, they knowingly engage in forbidden political activities. Yet, their protests prompt admiration and awards, rather than the pity and moral escapism other victims meet with. Their high ethical standards and their unwavering courage set them apart from run-ofthe-mill humanity. Unlike the dehumanized losers Rorty refers to, prisoners of conscience are deemed morally superior to the rest of us and portrayed as super-agentic and super-human.

Now, I don't deny that some people face danger in exemplary ways while others collapse, cower, or grovel. However, I'm suspicious of polarized representations of large morally significant categories of people. I have argued that it is factually and morally wrong to collaborate with the dehumanization of victims of genocide by tarring them with the brush of non-agency. Here I turn to the image of the super-human prisoner of conscience, which also stands in need of debunking.

For a Song and a Hundred Songs, Liao Yiwu's memoir of his years in detention as a political prisoner in China (1990-1994), provides an edifying corrective to typical media depictions of prisoners of conscience. Liao is a poet, now living in exile in Germany, who was inspired by the 1989 Tiananmen Square slaughter of pro-democracy activists to make a voice recording of his poem "Massacre" and to join with friends to create a film Requiem based on his poem of the same name. The first sixty pages of For a Song and a Hundred Songs telescope Liao's louche existence as an avant-garde poet - his exploitation of his wife, his promiscuity and drunkenness, his political alienation and cynicism - culminating with his uncharacteristic rage at the state's repression of peaceful protest and his arrest while attempting to spirit the tape of Requiem into clandestine channels in Beijing. More than three hundred pages follow chronicling his imprisonment - from his humiliating initiation by strip search to his release into a friendless world four years later.

Liao was extra-judicially incarcerated for his literary and cinematic expression of dissident political beliefs and for attempting to disseminate them. Yet personally he ill-fits the prisoner of conscience mold. Reproducing a conversation with a committed activist and fellow inmate, Liao faults himself:

Even now, I don't have a set of mature political views. I'm an individualist, with many incorrigible habits ... I was compelled to protest and put myself on a self-destructive path because the state ideology conflicted violently with the poet's right of free expression. ${ }^{17}$

Unlike the prisoners of conscience heralded in the international press who are represented as being moved by deeply held principles and acting for the common good, Liao professes self-interested motives and undisciplined resistance. But Liao is not given to false modesty. He fairly delights in describing his clever repartee during interrogation sessions, his defiance of prison guards' absurd commands, and his tangles with the

17. Liao Yiwu, For a Song and a Hundred Songs, trans. Wenguang Huang (Boston, MA: Houghton Mifflin Harcourt, 2013), pp. 363-4. 
inmate hierarchy. ${ }^{18}$ Still, he doesn't heroize himself. He candidly recounts the gamut of his responses to prison conditions, including behavior he regards as utterly disgraceful. ${ }^{19}$ And after enduring years of physical abuse and doggedly refusing to admit any wrongdoing, he relents: "In the end, I confessed all my crimes and pleaded guilty."20

For all I know, many prisoners of conscience are cut from nobler cloth. My purpose here isn't to sully anyone's reputation. But I do find it hard to believe that they act on purely altruistic motives and never succumb to fear or despair. Moreover, it would be wrong to exclude Liao from the category because he is no model of super-humanity. The Chinese state violated at least three of Liao's human rights - his right to freedom of opinion and expression, his right not to be subjected to arbitrary arrest and detention, and his right to a fair and public trial. ${ }^{21} \mathrm{He}$ was persecuted for expressing oppositional political beliefs. His characterological shortcomings do not impugn the judgment that he was a prisoner of conscience.

So far I have argued that testimonial evidence supports neither the dehumanization nor the super-humanization of victims of human rights abuse. If not, it is crucial to reconcile the persistence of attacks on human rights and victimization with a credible conception of common humanity. In the name of according all victims the respect they deserve, we need to couple destigmatizing victims of massacres and other atrocities with de-idealizing prisoners of conscience. In short, we need to conceptualize victimhood in a way that denies neither the human capacity for choice and action nor human weakness and vulnerability.

Prisoners of conscience are thought to exercise their agency in such a righteous way - non-violently and in pursuit of social justice - that they are super-humanized. By contrast, perpetrators of human rights abuse exercise their agency in such horrendous ways that paradoxically they share the fate of their victims - they too are dehumanized. Although Locke to my knowledge does not represent victims as dehumanized, we have seen that he does dehumanize perpetrators. The appeal of the thought that wrongdoers have taken leave of their humanity is never stronger than in cases of genocide.

In the late 1990s French journalist Jean Hatzfeld conducted in-depth interviews with fourteen survivors of the 1994 Rwandan genocide, and he subsequently returned to interview ten of the killers. Machete Season presents the testimony of a group of Hutu men who banded together to murder Tutsis and who were serving prison sentences for their genocidal acts at the time of the interviews. Hatzfeld deeply distrusts these interlocutors. $^{22}$ But by and large he lets them speak for themselves, and what they have to say is instructive, albeit marked by uncannily conflictive statements. I'll sample their testimony.

18. For example, Liao, pp. 91-3, 132-4, 178-9.

19. Liao, pp. $68,137-8,248,272-6$.

20. Liao, p. 309.

21. UDHR, Articles 19, 9, and 10.

22. Jean Hatzfeld, Machete Season: The Killers in Rwanda Speak, trans. Linda Coverdale (New York: Farrar, Straus and Giroux, 2005), p. 41. 
Interestingly, one interviewee expressly rejects Locke's suggestion that they lapsed into bestiality during the genocide and insists on how normally life went on apart from the daily killing stints in the forest. In Alphonse Hitiyaremye's words:

Some offenders claim that we changed into wild animals ... That is a trick to sidetrack the truth. I can say this: outside the marshes, our lives seemed quite ordinary. We sang on the paths, we downed Primus or urwagwa [locally produced banana beer], we had our choice amid abundance. We chatted about our good fortune, we soaped off our bloodstains in the basin, and our noses enjoyed the aromas of full cooking pots. We rejoiced in the new life about to begin by feasting on a leg of veal. We were hot at night atop our wives, and we scolded our rowdy children. Although no longer willing to feel pity, we were still greedy for good feelings ...

At the end of the season in the marshes, we were so disappointed we had failed [to exterminate the Tutsis]. ${ }^{23}$

These men hated the Tutsis, and they were licensed, in some ways goaded, to act on their hatred. They carried out the genocide diligently and methodically. They thought they were bettering themselves and their families.

Léopord Twagirayezu speaks of his skill as a killer and his coldblooded attitude towards his "work": "I want to make clear that from the first gentleman I killed to the last, I was not sorry about a single one." 24 He emphasizes that killing is easier work than farming and that he and his fellows were rewarded with healthy food, all the beer they cared to consume, and anything they could loot. ${ }^{25}$ Yet he broke down and loudly denounced himself for his crimes in a Congolese refugee camp, and later he confessed fully and cooperated extensively with the judicial authorities investigating the genocide. ${ }^{26}$ Moreover, he now reproaches himself for believing that "we could manage for ourselves without God." 27 Unlike some of the other members of his crew, he doesn't think he deserves to be forgiven by surviving Tutsis just because he is finally sorry for his genocidal zeal. ${ }^{28}$

Other subjects of Hatzfeld's interviews describe their guilty torments. For example, Fulgence Bunani blames himself for his suffering:

Me, I don't rid myself of the serious memories; I regret misjudging events and I regret the people who were killed. I thought wrong, I went wrong, I did wrong. An evil is spoiling my life, and my days are steeped in misery. ${ }^{29}$

Some of the prisoners are plagued by nightmares. ${ }^{30}$ One speaks of dissociation:

23. Hatzfeld, pp. 243-4, bracketed material added.

24. Hatzfeld, p. 51.

25. Hatzfeld, pp. 62, 147.

26. Hatzfeld, pp. 32-3, 164.

27. Hatzfeld, p. 147.

28. Hatzfeld, p. 206.

29. Hatzfeld, p. 157.

30. Hatzfeld, pp. 158-9. 
[I]t is as if I had let another individual take on my own living appearance, and the habits in my heart, without a single pang in my soul. This killer is indeed me, as to the offense he committed and the blood he shed, but he is a stranger to me in his ferocity. I admit and recognize my obedience at that time, my victims, my fault, but I fail to recognize the wickedness of the one who raced through the marshes on my legs, carrying my machete. The wickedness belongs to another self with a heavy heart. ${ }^{31}$

All were ruthless, merciless, machete-wielding murderers for six weeks, and they haven't magically morphed into choirboys. Striving to diffuse responsibility, they are sometimes defensive and evasive in their conversations with Hatzfeld. ${ }^{32}$ Still, they come across as complex human beings grappling as best they can with their shattering criminal acts.

When humanity is ascribed to someone, it can be a term of approbation that references the decency of the individual's conduct. The Hutu men's genocidal killing obviously disqualifies them from this sort of humanity. Nevertheless, their humanity as beings with intrinsic dignity in virtue of their capacities to reflectively choose and act remained intact throughout the genocide. This latter sort of humanity is called into question only if you altogether lose your ability to choose and act, not because you make bad choices and act badly. Your status as a bearer of human rights tracks the humanity common to agentic subjects, not the humanity of the morally good. For this reason, it is just as vital that these men be punished fairly as it is outrageous that Liao was punished at all. Had Locke not collapsed these two conceptions of humanity into a single attribute, his justification for punishment might have been more cogent.

By way of concluding, I would like to illustrate the usefulness of the foregoing reflections on our conceptions of victims and perpetrators in connection with the problem of human trafficking. In some destination countries, including the U.S. and Britain, immigration law distinguishes between foreign nationals who have been smuggled into the country and foreign nationals who have been trafficked into the country. ${ }^{33}$ Trafficked people are individuals who are induced to come to the destination country through force, fraud, or coercion. Some are abducted. Others believe deceptive recruitment offers of good jobs. Smuggled people are individuals who have hired or otherwise cooperated with a facilitator who promises to secure their entrance into the destination country. Some pay guides to escort them across borders by secret routes. Others knowingly go along with traffickers who provide false documents that enable them to gain entrance to a more affluent nation. Regardless of whether an individual is trapped in debt peonage or sold into forced labor upon arrival, smuggled people are subject to immediate deportation, whereas trafficked people are eligible for social services and material benefits, provided that they assist legal authorities in prosecuting their traffickers.

31. Hatzfeld, p. 48.

32. Hatzfeld, p. 155. In order to gain his subjects' confidence and obtain truthful testimony, Hatzfeld promised them that none of their testimony would be revealed to authorities or published until after their sentences were handed down and all appeals had been exhausted.

33. Louisa Waugh, Selling Olga: Stories of Human Trafficking and Resistance (London: Orion Books, 2006), p. 190. 
An undocumented transnational migrant's fate hangs on whether that individual is deemed an agent or a victim in the transport process. Smuggled people are considered agents punishable for committing the crime of illegal entry. Trafficked people are considered victims who may receive temporary aid and sometimes gain permanent residence and work permits. However the 2000 UN "Protocol to Prevent, Suppress and Punish Trafficking In Persons" recognizes that trafficking in persons can occur in transit, at the destination, or both. ${ }^{34}$ Thus Rey Koslowski points out that "a smuggled woman becomes a trafficking victim when she arrives at her destination and is forced into prostitution." 35 The same applies to all smuggled people who fall into the hands of traffickers or unscrupulous employers who subject workers to slavery-like conditions upon reaching their destination. Lacking visas that authorize them to work, smuggled migrants are exceedingly vulnerable to such criminal labor schemes. Setting aside the larger questions about the justice of exclusionary immigration policies that relatively prosperous states maintain, it is evident that the simplistic distinction between agents and victims that I have been at pains to critique ill-serves justice in the matter of undocumented migration.

Take, for example, the case of sex trafficking from the Global South to the Global North. Very few of the women trafficked into sex work fit the profile of a naïve country girl who has been duped about her future work abroad. ${ }^{36}$ Rather, these women are typically desperately poor and unable to adequately support themselves and meet the needs of their families in their home countries. ${ }^{37}$ Trying to solve their economic problems, they cooperate with traffickers even though they know they will be required to perform sex work upon arrival. ${ }^{38}$ Whether smuggled or trafficked in the transport process, sex workers who are trafficked at their destinations typically undergo severe and prolonged abuse that causes grave physical and psychological damage. Despite this commonality, the smuggled women do not count as victims because they initially cooperated with the

34. Under international law trafficking is defined as follows:

$[\mathrm{T}]$ he recruitment, transportation, transfer, harbouring or receipt of persons, by means of the threat or use of force or other forms of coercion, of abduction, of fraud, of deception, of the abuse of power or of a position of vulnerability or of the giving or receiving of payments or benefits to achieve the consent of a person having control over another person, for the purpose of exploitation.

http://www.unodc.org/unodc/en/human-trafficking/what-is-human-trafficking.html, accessed 8/16/2013.

35. Rey Koslowski, "Response to Harold Jongju Koh," in Displacement, Asylum, Migration, Ed. Kate E. Tunstall (Oxford: Oxford University Press, 2006), pp. 259-60.

36. Dina Francesca Haynes, "(Not) Found Chained to a Bed in a Brothel: Conceptual, Legal, and Procedural Failures to Fulfill the Promise of the Trafficking Victims Act," Georgetown Immigration Law Journal, 21 (2007), 337-81; Siddharth Kara, Sex Trafficking: Inside the Business of Modern Slavery, New York: Columbia University Press, 2009), p. 7; Waugh, pp. xiv, 63.

37. Suzanne Daley, "Rescuing Young Women from Traffickers' Hands." New York Times. http:// www.nytimes.com/2010/10/16/world/europe/16romania.html?_r=1\&emc=eta1, originally published 10/15/2010, accessed 12/21/2010; Kara, pp. 7, 23-30, 115, 142; Waugh, pp. 3, 73.

38. Waugh, pp. 37, 50, 63, 80, 142; Kara, p. 7. 
traffickers who subsequently abused them. ${ }^{39}$ Still, these women view themselves as agentic subjects who have been victimized. ${ }^{40}$

The revisions I have proposed in our conceptions of a victim and a perpetrator make room for their self-understanding. Yes, they undertook to cross international borders and work abroad without legally mandated papers. Yes, they were victimized - raped, beaten, held in debt peonage and/or confined to prison-like brothels. They are both agentic subjects and victims. But the 'smuggled migrant' category registers only the perpetrator half of this equation - their culpable complicity in the crime of undocumented migration. The victim half - the violations of their human rights - gets cancelled out in immigration hearings.

It should go without saying that this state of affairs is unjust. ${ }^{41}$ To my mind, it is a further reason to embrace the nuanced, realistic accounts of victims and perpetrators I advocate. The law ought to respect these women's humanity as subjects vulnerable to exploitation and violence together with their humanity as agents seeking economic betterment in a world of extreme inequality and closed sovereign borders. But as long as 'perpetrator' and 'victim' are mutually exclusive categories with perpetrators monopolizing agency and victims condemned to helplessness and passivity, there can be no such thing as a smuggled victim of sex trafficking. To remedy the injustices being done to many undocumented migrants who are trafficked when they reach destination countries, it is necessary to stop identifying innocence with passivity and helplessness and conditioning enforcement of human rights, especially the right to asylum, on satisfying that dehumanizing criterion. I have argued that we already possess a victim conception prisoners of conscience - that countenances certain forms of agency. We must now do the moral and juridical work of figuring out what kinds of agentic activity are compatible with victimization by trafficking and how immigration policies must be altered to respect the rights of these agentic victims. It is not enough for immigration policies to be attuned to whatever legitimate concerns about controlling borders there may be. They must also be attuned to the real perils of migration - the risks of falling prey to transnational criminal gangs - in our globalized labor market. The conceptual apparatus I endorse provides a framework that makes sense of the urgency of these tasks.

39. Zimmerman et al., Stolen Smiles: The Physical and Psychological and Health Consequences of Women and Adolescents Trafficked in Europe (London: London School of Hygiene and Tropical Medicine, 2006) http://genderviolence.lshtm.ac.uk/?s=stolen+smiles (accessed 8/17/2013); Kara, pp. 115, 143; Waugh, pp. 25, 33, 80-81.

40. Waugh, p. 39.

41. For related discussion, see Jayashri Srikantiah, "Perfect Victims and Real Survivors: The Iconic Victim in Domestic Human Trafficking Law," Boston University Law Review 87 (2007), 157-211; Dina Francesca Haynes, "Used, Abused, Arrested, and Deported: Extending Immigration Benefits to Protect the Victims of Trafficking and to Secure the Prosecution of Traffickers," in Women's Rights: A Human Rights Quarterly Reader. ed. Bert B. Lockwood (Baltimore, MD: Johns Hopkins University Press, 2006); Julietta Hua, Trafficking Women's Human Rights (Minneapolis, MN: University of Minnesota Press, 2011). 